

Ralph Bunche Summer Institute Closing Banquet: Back Row (L-R), Professor Paula D. McClain, Stan Humphries (Graduate Assistant), Professor Steven Finkel (Director), Reggie McGahee, Damian Goodman, Travis Simmons, Michael Salmon. Middle Row (L-R), Alan Kedrick (Graduate Assistant), Vincet Ward, Dana Lee Olds, Jhamed Babatunde-Bey, Duane Crooks, Sherrie Green, April Hahn (Assistant Director). Front Row (L-R): Fatima Goss, Jeff Gulati (Graduate Assistant), Khalilah Brown, Demecher Ware, Tashna Brightwell, Tiffany Miller. Not in photo: Lakisha Fields, Jay Shaylor (Graduate Assistant).

ready been named assistant professors at the university level.

Eleven departments of political science sent recruiters, at their own expense, to the Institute to interest the Bunche students in their graduate programs and to invite applications. Kaplan Educational Center supports the program by sending a representative to the Institute each summer to help students prepare to take the Graduate Record Examinations.

The Institute adjourned with a Closing Banquet held at the Ivy Inn in Charlottesville. APSA President Elinor Ostrom and APSA Executive Director Catherine Rudder spoke to the students. Bennet Bertenthal, Association Director for Social and Behavioral Sciences, Frank Scioli and Rick Wilson, Program Directors in the Social, Behavioral and Economic Research Office attended the banquet on behalf of the National Science Foundation, which supports the program through a generous grant. Representing the University of Virginia administration was Alex Johnson, Vice Provost for Faculty Recruitment and Retention. The APSA extends heartfelt appreciation to RBSI Director Steve Finkel, Professor Paula McClain, Assistant Director April Hahn, and Graduate Student Assistants, Jay Shaylor, Alan Kendrick, Jeff Gulati, and Stan Humphries for their dedication to the mission of the Institute.

The 1997 Ralph Bunche Summer Institute participants included: Tashna Joeline Brightwell, Xavier University (LA); Khalilah La'Shea Brown, University of Virginia; Lakisha Danielle Fields, South Carolina State University; Fatima Ayanna Goss, University of California-Los Angeles; Tiffany Diane Miller, Kent State University; Demecher Devon Ware, Mississippi Valley State University; Dana Lee Olds, Lincoln University; Jhamed Babatunde-Bey, University of California-Los Angeles; Duane A. Crooks, University of Miami; Michael George Salmon, University of Miami; Travis Tremain Simmons, North Carolina A\&T State University; Vincent James Ward, University of New Mexico; Damian Christian Goodman, Providence College; Sherrie Green, Wellesley College; and Reginald Avis McGahee, South Carolina State University.
National Science Foundation, APSA, University of Virginia, and Others Support the 1997 Ralph Bunche Summer Institute

The National Science Foundation (NSF) has contributed $\$ 246,000$ to the University of Virginia (UVA) in order to support the Ralph Bunche Summer Institute in 1997 and for two subsequent years. UVA initiated its financial support when it first hosted the Institute in 1996. Now in its eleventh year, the Ralph Bunche Institute is a five-week academic program for exceptional African American juniors and seniors designed to introduce them to the world of graduate study and encourage their application to Ph.D. programs in political science. Through the efforts of UVA President John Casteen, Provost Peter Low, Vice Provost Alex Johnson, and Dean of the Faculty of Arts and Sciences Ray Nelson, UVA has also contributed $\$ 108,000$ to assist the Institute through the summer of 1999. President Casteen has continued to make available University resources in order to ensure that the Institute can be held without interruption and to enable the University to raise outside funds in subsequent years. These contributions from the NSF and UVA, combined with $\$ 8000$ of support from the APSA and facility support from UVA's Department of Government and Foreign Affairs, have enabled 15 students to participate in the program for the summer of 1997 and 6 students to attend the APSA's Annual Meeting in Washington, DC, August 28-31.

\section{Minority ID Project's New Spring Round a Success}

The Minority Identification Project identified an additional 50 minority undergraduate students in its new Spring Round, adding to the list of 275 students who were named in the Project earlier in the 1996-97 academic year.

The Minority ID Project is a collective effort of APSA, undergraduate faculty, and graduate schools and is designed to increase the number 